\title{
Early magnesium discontinuation postpartum and eclampsia risk: a systematic review and meta-analysis
}

\author{
Johanna Quist-Nelson ${ }^{1}$, Annemijn de Ruigh ${ }^{2}$, Eva Pajkrt ${ }^{3}$, Ben $\mathrm{Mol}^{4}$, Paulino Vigil-De \\ Gracia $^{5}$, Jack Ludmir ${ }^{6}$, Lukas Staub ${ }^{7}$, Lisa Askie ${ }^{7}$, and Vincenzo Berghella ${ }^{6}$ \\ ${ }^{1}$ Thomas Jefferson university Hospital \\ ${ }^{2}$ AMC Afdeling voor Verloskunde Gynaecologie \\ ${ }^{3}$ University of Amsterdam \\ ${ }^{4}$ Monash University Medical Centre \\ ${ }^{5}$ Caja de Seguro Social Panama \\ ${ }^{6}$ Thomas Jefferson University \\ ${ }^{7}$ The University of Sydney
}

May 5, 2020

\begin{abstract}
Background: The optimal duration of magnesium administration postpartum for prevention of eclampsia has not yet been established. Objective: To investigate the effect of early discontinuation of postpartum magnesium on the rates of postpartum eclampsia when compared to continuation for 24-hour postpartum. Search Strategy: Searches were performed using keywords related to "preeclampsia" and "magnesium sulfate" from inception of database until March 2019. Selection Criteria: Randomized controlled trials of women with preeclampsia receiving magnesium prior to delivery randomized to early discontinuation of magnesium postpartum. The control group was 24-hours of magnesium postpartum. Data Collection and Analysis: The primary outcome was the rate of postpartum eclampsia. Main Results: Eight RCTs with 2,183 women were included with five different magnesium administration time-frames. Eclampsia rates were not different between the two groups (5/1,088 (0.5\%) after early discontinuation, versus $2 / 1,095(0.2 \%)$ in the 24 -hour group; RR $2.25,95 \%$ CI $0.5-9.9$, I2=0\%, 8 studies, 2,183 participants). A number needed to treat was calculated; 370 women would need to receive 24-hours of magnesium postpartum to prevent one episode of postpartum eclampsia. The early discontinuation group had a significant decrease in time to ambulation and breastfeeding. Conclusions: Compared to continuation of magnesium for 24 hours postpartum, early magnesium discontinuation postpartum does not significantly increase the rate of postpartum eclampsia. The largest proportion of women did not receive magnesium postpartum after receiving at least 8 grams intrapartum, thus it is reasonable to consider discontinuation of magnesium postpartum if a woman has received similar adequate dose prior to delivery.
\end{abstract}

\section{Introduction}

Preeclampsia is a multisystem disorder affecting mother and fetus that complicates $2-8 \%$ of pregnancies and causes $10-15 \%$ of direct maternal mortality worldwide. ${ }^{1,2}$ Eclampsia is diagnosed when a woman with preeclampsia experiences generalized convulsions and further increases the risk for maternal and neonatal mortality. ${ }^{3}$ In $72-86 \%$ of cases eclampsia occurs antepartum or intrapartum, but can occur at any time, including postpartum. ${ }^{3}$ In order to decrease the risk of eclampsia, magnesium sulfate is administered to women with pre-eclampsia with severe features through continuous intravenous (IV) infusion or intramuscular (IM) injections intrapartum, and may be continued postpartum. The American College of Obstetricians and Gynecologists (ACOG) has recommended that magnesium continue for 24 hours postpartum for women with preeclampsia with severe features. ${ }^{4}$ Notably, magnesium infusion has been shown to have multiple side 
effects including maternal flushing, and sedation. Occasionally more severe side effects are noted in the case of magnesium toxicity, for example $1.3 \%$ of women receiving magnesium infusion can experience maternal respiratory depression. ${ }^{5,6}$ Given these side effects and risks as well as the lower rate of eclampsia in the postpartum period ( $14 \%$ of all episodes of eclampsia ${ }^{3,6}$ ) consideration has been given to early discontinuation of magnesium during the postpartum period in several randomized controlled trials (RCTs).

Our objective was to investigate the effect that early magnesium discontinuation has on the rates of postpartum eclampsia when compared to the standard 24-hour regimen by performing a systematic review and meta-analysis. Our secondary objective was to assess postpartum patient-care parameters for each group by examining time to ambulation, time to initiation of breastfeeding, and length of maternal stay.

Methods The systematic review and meta-analysis was reported following the Preferred Reporting Item for Systematic Reviews and Meta-analyses (PRISMA) statement standards. ${ }^{7}$ The research protocol was designed a priori, defining methods for searching the literature, assessing studies for inclusion, and extracting and analyzing data. The research protocol was registered with the PROSPERO International Prospective Register of Systematic Reviews (CRD42019127167). Searches were performed in MEDLINE, OVID, Scopus, World Health Organization (WHO) International Clinical Trials Registry Platform (ICTRP), ClinicalTrials.gov and the Cochrane Central Register of Controlled Trials with the use of a combination of keywords and text words related to "magnesium," "magnesium sulfate," and "preeclampsia" from inception of each database until March 2019 (Appendix S1 contains search strategy). To locate additional publications, we reviewed bibliographies of identified studies and review articles. No restrictions for language or geographic location were applied.

Study Selection We included all RCTs studying women with preeclampsia and receiving magnesium prior to delivery that were subsequently randomized to a shorter duration $(<24$ hours) of magnesium administration postpartum or to the standard 24-hour duration. Notably, the intervention group (shorter duration) included studies where no magnesium was administered postpartum as well as when magnesium was continued for less than 24 hours. In the control group for all included studies, the women received the standard 24-hour regimen administration postpartum. Exclusion criteria were studies involving medications other than magnesium for seizure prophylaxis, preeclampsia diagnosed in the postpartum period, studies examining only women with eclampsia and studies where the control group received less than 24 hours of magnesium.Assessment of included trial quality Trial registration number, ethics approval and trial protocolFor each included trial, registration numbers were obtained from searching the WHO ICTRP and Clinicaltrials.gov by two authors (JQN and AdR) and timing of trial registration was recorded (prospectively or retrospectively). If no trial registration number could be found, trialists were contacted to confirm registration. All included studies were asked for a statement confirming ethics approval and a trial protocol. If trials were registered retrospectively, trialists were contacted to confirm ethics approval and a pre-specified trial protocol before start of recruitment and were asked to explain reasons for retrospective trial registration. If no response, at least two more attempts were made to contact trialists.

Review statistical methods of included studiesThe statistical methods described and used in each included trials were reviewed by two authors (JQN, AdR). The following issues were assessed: 1) consistency between the (pre)specified statistical methods in the trial protocol (or pre-specified data analysis plan) (if available) and the statistical methods used in the published manuscript, 2) a clear and detailed description of the statistical methods used (making trial results reproducible) (if available), 3) consistency between the specified method and what is presented in the results section (including tables and figures), 4) use of the appropriate statistical methods given the data type (e.g. possible errors that could be identified: use of a paired sample t-test, to determine whether the mean difference between two sets of observations is zero in two independent treatment arms). Judgments were categorized as "yes", "no" or "unclear risk". Trialists of included studies were contacted in case of any lack of clarity regarding trial methods or results, inconsistency in rates of reported outcome events, or results that contained number patterns unlikely to be randomly resulted, or improper interim analyses. If no response, at least two more attempts were made to contact trialists. Risk of bias The risk of bias in each included trial was assessed by two authors (JQN and AdR) using the criteria 
outlined in the Cochrane Handbook for Systematic Reviews of Interventions. ${ }^{8}$ Seven domains related to risk of bias were assessed in each included trial since there is evidence that these issues are associated with biased estimates of treatment effect: 1) random sequence generation; 2) allocation concealment; 3) blinding of participants and personnel; 4) blinding of outcome assessment; 5) incomplete outcome data; 6) selective reporting; and 7) other bias. Review authors' judgments were categorized as "low risk", "high risk" or "unclear risk" of bias.

Outcomes The primary outcome was the rate of postpartum eclampsia, occurring up until six weeks postpartum, with time frame as reported by study. Secondary maternal postpartum outcomes were maternal respiratory depression, severe hypertension, maternal death, need to extend magnesium therapy, amount of magnesium sulfate (grams) received, time to ambulation (hours), time to initiation of breastfeeding (hours), duration of urinary catheter (hours), postpartum medications for hypertension, antihypertensive therapy at discharge, postpartum hospital stay (days) by mode of delivery, and maternal satisfaction.

We planned subgroup analyses for the primary outcome for studies allocating women to no postpartum magnesium, as well as 6 and 12 hours of postpartum magnesium. Additionally, we planned a sensitivity analysis for preeclampsia without severe features (identified as mild preeclampsia in some studies) and preeclampsia with severe features.

Furthermore, we planned a sensitivity analysis for studies judged to be at low risk of bias based off Cochrane handbook assessment.Statistical analysis Data abstraction was completed by two independent investigators (JQN and AdR). Each investigator independently abstracted data from each study and analyzed data separately using Review Manager 5.3 (The Nordic Cochrane Centre, Cochrane Collaboration, 2014, Copenhagen, Denmark). The completed analyses were then compared, and any difference was resolved with review of the entire data and independent analysis. Additional discrepancies were settled by discussion with a third author (VB).

Data from each eligible study were extracted without modification of original data. A 2 by 2 table was assessed for the relative risk (RR); for continuous outcomes means and standard deviations were extracted and imported into Review Manager v. 5.3 (The Nordic Cochrane Centre, Cochrane Collaboration, 2014, Copenhagen, Denmark).

Meta-analysis was performed using the random effects model of DerSimonian and Laird, to produce summary treatment effects in terms of RR or mean difference (MD) with a $95 \%$ confidence interval (CI). Heterogeneity was measured using I-squared (Higgins $\mathrm{I}^{2}$ ). Potential publication biases were assessed statistically by using Begg's and Egger's tests when more than 10 publications with the primary outcome were available on the topic. A p value $<0.05$ was considered statistically significant.

Results Eight trials met the inclusion criteria for this meta-analysis with a total of 2,183 participants (1,088 in early magnesium group versus 1,095 in 24-hour regimen) (Table 1) ${ }^{9-16}$ Figure 1 shows the flow diagram (PRISMA template) of records reviewed. Table S1 has characteristics of excluded studies. Table S2 reports on trial registration number, trial protocol, and ethical approval. Five of the trials were registered; only one trial underwent trial registration in a prospective fashion. ${ }^{16}$ Contact was made with seven trials and the authors of four of the included trials provided additional study information on request. ${ }^{12,13,15,16} \mathrm{~A}$ review of the statistical methods used by the included studies did not reveal any discrepancies (Table S3). Three studies had an overall low risk of bias for all key domains as assessed by the Cochrane Collaboration's tool (Figure 2) ${ }^{13,15,16}$ Four studies had unclear or high risk of bias in allocation concealment and selective reporting. ${ }^{9,11,12,14}$ None of the studies were double-blinded, thus all were judged to be at high risk of performance bias as assessed by the Cochrane Collaboration's tool. Publication bias was not assessed as less than 10 publications with the primary outcome were included.

Seven trials ${ }^{9,11-15}$ included only women with preeclampsia with severe features, and two trials of 1,397 patients included in this meta-analysis used the definition of preeclampsia with severe features by ACOG criteria. ${ }^{14,15}$ There were five different time frames for early magnesium discontinuation (Table 1): 1). Loading dose of magnesium only, one trial, ${ }^{14} 2$ ). No magnesium given postpartum, one trial, ${ }^{16} 3$ ). Magnesium 
administration until diuresis, one trial, $\left.{ }^{11} 4\right)$. Six hours of postpartum magnesium, two studies, $\left.{ }^{9,15} 5\right)$. Twelve hour postpartum regimen of magnesium, three studies. ${ }^{10,12,13}$ Table S4 details inclusion/exclusion criteria and magnesium dosing used in each study and Table S5 details maternal characteristics at randomization.

Average maternal age at time of randomization was 25.8 versus 26.3 years. The majority of women were nulliparous; twin pregnancies (when reported) constituted a small proportion of studied women $(0.7-3.6 \%, 3$ studies) (Table S5). ${ }^{13,15,16}$ Only two studies ${ }^{12,16}$ reported on the use of antihypertensive medication antepartum $(187 / 637(29.4 \%)$ versus 197/646 (30.5\%), 2 studies) or during labor (24/154 (15.6\%) versus 31/166 (18.7\%), 2 studies). ${ }^{9,12}$ The mean gestational age (GA) at delivery was 36.3 versus 36.5 weeks (Table 2) with a large percentage of women were delivered via cesarean delivery $(571 / 1011(56.5 \%)$ versus 562/1,002 (56.9\%), 8 studies). ${ }^{9-16}$ Eclampsia rates were no different between the two groups $(5 / 1,088$ (0.5\%), versus 2/1,095 (0.2\%); RR 2.3, 95\% CI 0.5-9.9, $\mathrm{I}^{2}=0 \%, 8$ studies, 2,183 participants) (Table 3). ${ }^{9-16}$ The details of the seven women with eclampsia are presented in Table 4 . One women was being treated with magnesium when she experienced eclampsia; three were not being treated with magnesium at the time of her eclampsia. For all other women the details were not reported and were unavailable when additional data was sought from the authors. Further detail on women with eclampsia including the number of episodes, the pre-existing symptoms and the amount of magnesium received prior to eclampsia were not reported.

Regarding secondary outcomes (Tables 3 and 5), there was a significant decrease in time to ambulation in the early discontinuation group (MD -9.1 hours, 95\% CI -14.7-(-3.6), $\mathrm{I}^{2}=98 \%, 3$ studies, 1,509 participants) ${ }^{13,15,16}$ and in time to initiation of breastfeeding (MD -8.4 hours, 95\% CI -12.0-(-4.8), $\mathrm{I}^{2}=60 \%, 2$ studies, 1,397 participants). ${ }^{15,16}$ Only one study reported on the duration of the urinary catheter, and demonstrated a shorter duration in the early discontinuation group. ${ }^{13}$ Magnesium therapy was extended past planned duration more commonly in the early magnesium discontinuation group, (15/961 (1.6\%) versus 3/954 (0.3\%), RR 3.7, 95\% CI 1.2-11.5, $\mathrm{I}^{2}=0 \%, 7$ studies, 2,006 participants). ${ }^{9,10,12-16}$ Length of stay in the hospital, reported in three studies, was only available for combined modes of delivery, and was not different between groups (Table 5). ${ }^{10,11,14} \mathrm{~A}$ total of four studies reported on severe consequences of magnesium toxicity such as respiratory or cardiac arrest, and death and no differences were seen between study groups. ${ }^{13-16}$ The more commonly reported maternal adverse effects such as flushing, nausea, vomiting, and headaches, were also not reported by any of the included trials.

Robust data was not available for antihypertensive therapy during hospitalization postpartum (1 study, $300 / 558(53.7 \%)$ versus $283 / 555(51.0 \%))^{16}$ or at discharge (1 study, 30/48 (63\%) versus $\left.23 / 50(46 \%)\right) .{ }^{11}$ Only one study with 112 women reported on maternal satisfaction and noted a higher satisfaction with early discontinuation of magnesium, but this finding was not statistically significant. ${ }^{13}$ Subgroup analyses and sensitivity analyses, which were conducted for the primary outcome, did not reveal any increased risk of eclampsia, including discontinuing magnesium immediately postpartum or at 6 or 12 hours (Figure S1).

Discussion This meta-analysis demonstrates that early discontinuation of magnesium postpartum does not significantly increase the rates of eclampsia when compared to a 24-hour regimen. Though only reported by three trials, in the early discontinuation group there is a significant improvement in postpartum quality indicators such as decrease in time to ambulation, time to initiation of breastfeeding, as well as duration of urinary catheter. The rate of cesarean delivery was high in included studies, likely related to geographic variation. Subgroup analyses, conducted for the primary outcome, did not reveal any increased risk of eclampsia in any subgroups including discontinuing magnesium immediately postpartum or at six or 12 hours.

While not significant, there was a higher incidence of eclampsia in the early discontinuation group (5/1,088 (0.5\%) early discontinuation, vs 2/1,095 (0.2\%) 24-hour group). When using this rate (absolute risk reduction of -0.0027) to calculate a number needed to treat (NNT), 370 women would need to receive the standard 24 -hr regimen to prevent one episode of eclampsia. This is similar to the notable NNT is the rate of $1 / 400$ in preeclampsia without severe features for which magnesium is not routinely recommended. ${ }^{19}$ Table 6 provides additional scenarios where clinicians could consider early discontinuation of magnesium as well as patients who would benefit from continuation for the standard 24-hour regimen. Notably, as neurologic symptoms 
have the highest correlation with risk of eclampsia with a NNT of $1 / 36,{ }^{19}$ providers may want to consider the standard 24-hour regimen in women with such symptoms.

The strengths of this meta-analysis are that it follows the PRISMA guidelines and includes studies without restriction to publication date or language. This study examined not only the risk of bias but also closely examined trial methodology, such as trial registration timing, confirmation of ethics approval, and a review of statistical methods. This provides the reader additional information to assess methodological quality, and evaluate data integrity and transparency. All included studies reported on the primary outcome, the risk of eclampsia.

This meta-analysis is not without limitations; many of which are inherent to those limitations of any metaanalysis as well as the included trials. For example the included trials use five different time frames to administer magnesium postpartum (loading dose only, no postpartum magnesium, six hours, 12 hours, or until diuresis took place). With such heterogeneity in study design, the results may be interpreted with caution, as the optimal timing of postpartum magnesium administration has not been established by this meta-analysis. Additionally, a large proportion of these women come from two large trials located in Latin America and thus the external validity of these data may be questioned. Lastly, the lack of difference between groups may be secondary to a lack of power. If the eclampsia rates of $0.5 \%$ in the early discontinuation group vs $0.2 \%$ in the 24 -hour group were used to perform a sample size calculation with power of 0.8 and alpha of 0.05 , then a total of 12,164 women would need to be randomized, with 6,082 in each group. Until a larger trial is performed, this meta-analysis remains the most comprehensive review of the literature. Our results reflect the results of each of the included individual studies, that the rate of eclampsia is not significantly different when magnesium is discontinued early. The Cochrane Review by Duley et al published in 2010 examined alternative regimens for women with preeclampsia as well as eclampsia. ${ }^{6}$ They included a total of four studies, two of the studies included in this review, and concluded that there were too few published data to make any reliable conclusions regarding duration of treatment postpartum. ${ }^{10,11}$ We have expanded upon the Cochrane Review by including a total of eight randomized controlled studies. Eclampsia rates remain low, with a total of seven eclamptic events, which is a total rate of $0.3 \%$. Given this low rate of eclampsia, it is clear that the administration of magnesium remains clinically effective and the standard of care for treatment of preeclampsia with severe features. ${ }^{6,17}$ This study expands on the information available in the Cochrane review by including the secondary postpartum outcomes, including time to ambulation, time to breastfeeding, duration of urinary catheter placement, and length of time in the hospital. This review shows that all of these findings were significantly improved by the shorter magnesium regimen. These quality measures call into question the recommendation to continue magnesium for 24 hours postpartum. ${ }^{18}$

Conclusion

Compared to continuation of magnesium for 24-hours postpartum, early magnesium discontinuation postpartum does not significantly increase the rate of postpartum eclampsia. The largest proportion of women did not receive magnesium postpartum after receiving at least 8 grams intrapartum, thus it is reasonable to consider discontinuation of magnesium postpartum if a woman has received similar adequate dose prior to delivery.Disclosure of interests : Dr. Ben Willem Mol is supported by a NHMRC Practitioner Fellowship (GNT1082548). Dr. Ben Willem Mol reports consultancy for ObsEva, Merck Merck KGaA and Guerbet. Dr Jack Ludmir and Dr Paulino Vigil-de Gracia were both authors on included randomized trials. The other authors did not report any potential conflicts of interest.

Contribution to authorship : JQN, AdR, and VB were involved in the conception of this meta-analysis. JQN, AdR, BM, EP, PVG, JL, LS and LA were involved in the planning and carrying out of the project. JQN, AdR performed the analysis and wrote the manuscript. The manuscript was approved by all authors.

Details of ethics approval : This project was exempt from Institutional Review Board.

Funding : No funding was used for this meta-analysis.

Acknowledgements: We would like to acknowledge Dr. Maryam Kashanian, Dr Melania Amorim and Dr 
Sabina Maia who provided unpublished data for inclusion in this meta-analysis.

\section{REFERENCES}

1. Steegers EA, von Dadelszen P, Duvekot JJ, Pijnenborg R. Pre-eclampsia. Lancet 2010; 376 (9741): $631-44$.

2. Duley L. The global impact of pre-eclampsia and eclampsia.Semin Perinatol 2009; 33 (3): 130-7.

3. Liu S, Joseph KS, Liston RM, et al. Incidence, risk factors, and associated complications of eclampsia. Obstet Gynecol 2011;118 (5): 987-94.

4. ACOG Practice Bulletin No. 202: Gestational Hypertension and Preeclampsia. Obstet Gynecol 2019; 133 (1): e1-e25.

5. Smith JM, Lowe RF, Fullerton J, Currie SM, Harris L, Felker-Kantor E. An integrative review of the side effects related to the use of magnesium sulfate for pre-eclampsia and eclampsia management. $B M C$ Pregnancy Childbirth 2013; 13 : 34.

6. Duley L, Gulmezoglu AM, Henderson-Smart DJ, Chou D. Magnesium sulphate and other anticonvulsants for women with pre-eclampsia. Cochrane Database Syst Rev 2010; (11): CD000025.

7. Moher D, Shamseer L, Clarke M, et al. Preferred reporting items for systematic review and meta-analysis protocols (PRISMA-P) 2015 statement. Syst Rev 2015; 4 : 1.

8. Higgins JPT GS, Sally E, Cochrane Collaboration. Cochrane handbook for systematic reviews of interventions. Chichester, England: Wiley-Blackwell; 2011. .

9. Darngawn L, Jose R, Regi A, Bansal R, Jeyaseelan L. A shortened postpartum magnesium sulfate prophylaxis regime in pre-eclamptic women at low risk of eclampsia. Int J Gynaecol Obstet 2012;116 (3): 237-9.

10. Ehrenberg HM, Mercer BM. Abbreviated postpartum magnesium sulfate therapy for women with mild preeclampsia: a randomized controlled trial.Obstet Gynecol 2006; 108 (4): 833-8.

11. Fontenot MT, Lewis DF, Frederick JB, et al. A prospective randomized trial of magnesium sulfate in severe preeclampsia: use of diuresis as a clinical parameter to determine the duration of postpartum therapy.Am J Obstet Gynecol 2005; 192 (6): 1788-93; discussion 93-4.

12. Kashanian M, Koohpayehzadeh J, Sheikhansari N, Bararpour F, Sahraian G, Asadolla S. A comparison between the two methods of magnesium sulfate administration for duration of 12 versus $24 \mathrm{~h}$ after delivery in patients with severe preeclampsia. J Matern Fetal Neonatal Med 2016;29 (14): 2282-7.

13. Maia SB, Katz L, Neto CN, Caiado BV, Azevedo AP, Amorim MM. Abbreviated (12-hour) versus traditional (24-hour) postpartum magnesium sulfate therapy in severe pre-eclampsia. Int J Gynaecol Obstet2014; 126 (3): 260-4.

14. Rimal SP, Rijal P, Bhatt R, Thapa K. Loading Dose only versus Standard Dose Magnesium Sulfate Seizure Prophylaxis in Severe Pre-eclamptic Women. JNMA J Nepal Med Assoc 2017;56 (208): 388-94.

15. Vigil-De Gracia P, Ramirez R, Duran Y, Quintero A. Magnesium sulfate for 6 vs 24 hours post delivery in patients who received magnesium sulfate for less than 8 hours before birth: a randomized clinical trial. $B M C$ Pregnancy Childbirth 2017; 17 (1): 241.

16. Vigil-DeGracia P, Ludmir $\mathrm{J}, \mathrm{Ng} \mathrm{J}$, et al. Is there benefit to continue magnesium sulphate postpartum in women receiving magnesium sulphate before delivery? A randomised controlled study. BJOG2018; 125 (10): 1304-11.

17. Altman D, Carroli G, Duley L, et al. Do women with pre-eclampsia, and their babies, benefit from magnesium sulphate? The Magpie Trial: a randomised placebo-controlled trial. Lancet 2002;359 (9321): 
1877-90.

18. Anjum SG, Nidhi \& Alvi, Yasir \& R. Gade, Pramod \& Bano, Imam. (2017). Maternal Outcome with Discontinuation of Magnesium Sulfate immediately Postpartum in Severe Preeclampsia. 9. 84-7. 10.5005/jpjournals-10006-1464. .

19. Sibai BM. Magnesium sulfate prophylaxis in preeclampsia: Lessons learned from recent trials. Am $J$ Obstet Gynecol 2004;190 (6): 1520-6.

\section{FIGURE LEGENDS}

Figure 1 - PRISMA (Preferred Reporting Items for Systematic Review and Meta-Analyses) flow diagram of records reviewed

Figure 2- Risk of Bias assessment A. Risk of bias summary: review authors' judgements about each risk of bias item for each included study. B. Risk of bias graph: review authors' judgements about each risk of bias item presented as percentages across all included studies.Figure 3 - Forest plot of primary outcome, rate of eclampsia in women receiving early magnesium discontinuation postpartum versus standard 24-hour regimen

\section{TABLES}

Table 1. Characteristics of included randomized controlled trials (Magnesium early discontinuation versus standard 24-hour regimen)

\begin{tabular}{|c|c|c|c|c|c|c|}
\hline Study & $\begin{array}{l}\text { Sample } \\
\text { size of } \\
\text { included } \\
\text { women }\end{array}$ & $\begin{array}{l}\text { Countries } \\
\text { of recruit- } \\
\text { ment }\end{array}$ & Blinded & Intervention & Comparator & $\begin{array}{l}\text { Primary } \\
\text { outcome }\end{array}$ \\
\hline $\begin{array}{l}\text { Fontenot, } \\
2005\end{array}$ & 98 (48 vs 50$)$ & $\begin{array}{l}\text { United } \\
\text { States of } \\
\text { America }\end{array}$ & No & $\begin{array}{l}\text { Received } \\
\text { minimum of } \\
2 \text { hour } \\
\text { magnesium } \\
\text { therapy } \\
\text { until the } \\
\text { onset of } \\
\text { diuresis } \\
\text { (urine } \\
\text { output }>100 \\
\text { mL/hour for } \\
2 \\
\text { consecutive } \\
\text { hours) }\end{array}$ & $\begin{array}{l}\text { Magnesium } \\
\text { for } 24 \text { hours } \\
\text { postpartum }\end{array}$ & NR \\
\hline $\begin{array}{l}\text { Ehrenberg, } \\
2006\end{array}$ & $\begin{array}{l}196(101 \text { vs } \\
95)\end{array}$ & $\begin{array}{l}\text { United } \\
\text { States of } \\
\text { America }\end{array}$ & No & $\begin{array}{l}12 \text { hours of } \\
\text { postpartum } \\
\text { magnesium }\end{array}$ & $\begin{array}{l}\text { Magnesium } \\
\text { for } 24 \text { hours } \\
\text { postpartum }\end{array}$ & $\begin{array}{l}\text { Duration of } \\
\text { magnesium } \\
\text { therapy }\end{array}$ \\
\hline $\begin{array}{l}\text { Darngawn, } \\
2012\end{array}$ & $\begin{array}{l}150 \text { (75 vs } \\
75)\end{array}$ & India & No & $\begin{array}{l}6 \text { hours - } \\
\text { injections of } \\
\text { magnesium } \\
\text { were } \\
\text { discontinued }\end{array}$ & $\begin{array}{l}\text { Magnesium } \\
\text { injections } \\
\text { for } 24 \text { hours } \\
\text { postpartum }\end{array}$ & $\mathrm{NR}$ \\
\hline Maia, 2014 & $112(56$ vs 56$)$ & Brazil & No & $\begin{array}{l}12 \text { hours of } \\
\text { postpartum } \\
\text { magnesium }\end{array}$ & $\begin{array}{l}\text { Magnesium for } \\
24 \text { hours } \\
\text { postpartum }\end{array}$ & $\begin{array}{l}\text { Duration of } \\
\text { anticonvulsant } \\
\text { therapy } \\
\text { postpartum }\end{array}$ \\
\hline
\end{tabular}




\begin{tabular}{|c|c|c|c|c|c|c|}
\hline Study & $\begin{array}{l}\text { Sample } \\
\text { size of } \\
\text { included } \\
\text { women }\end{array}$ & $\begin{array}{l}\text { Countries } \\
\text { of recruit- } \\
\text { ment }\end{array}$ & Blinded & Intervention & Comparator & $\begin{array}{l}\text { Primary } \\
\text { outcome }\end{array}$ \\
\hline $\begin{array}{l}\text { Kashanian, } \\
2016\end{array}$ & $\begin{array}{l}170 \text { (79 vs } \\
91)\end{array}$ & Iran & No & $\begin{array}{l}12 \text { hours of } \\
\text { postpartum } \\
\text { magnesium }\end{array}$ & $\begin{array}{l}\text { Magnesium } \\
\text { for } 24 \text { hours } \\
\text { postpartum }\end{array}$ & Convulsion \\
\hline $\begin{array}{l}\text { Rimal, } \\
2017\end{array}$ & $60(30$ vs 30$)$ & Nepal & No & $\begin{array}{l}\text { Loading } \\
\text { dose of } \\
\text { magnesium } \\
\text { antepartum } \\
\text { only }\end{array}$ & $\begin{array}{l}\text { Magnesium } \\
\text { for } 24 \text { hours } \\
\text { postpartum }\end{array}$ & NR \\
\hline $\begin{array}{l}\text { Vigil-De } \\
\text { Gracia, } \\
2017\end{array}$ & $\begin{array}{l}284(141 \text { vs } \\
143)\end{array}$ & Panama & No & $\begin{array}{l}6 \text { hours of } \\
\text { postpartum } \\
\text { magnesium }\end{array}$ & $\begin{array}{l}\text { Magnesium } \\
\text { for } 24 \text { hours } \\
\text { postpartum }\end{array}$ & $\begin{array}{l}\text { Eclampsia in } \\
\text { the first } 72 \\
\text { hours } \\
\text { postpartum }\end{array}$ \\
\hline $\begin{array}{l}\text { Vigil-De } \\
\text { Gracia, } \\
2018\end{array}$ & $\begin{array}{l}1113(558 \text { vs } \\
555)\end{array}$ & $\begin{array}{l}\text { Dominican } \\
\text { Republic, } \\
\text { Ecuador, El } \\
\text { Salvador, } \\
\text { Panama, } \\
\text { Peru }\end{array}$ & No & $\begin{array}{l}\text { No } \\
\text { magnesium } \\
\text { sulfate } \\
\text { postpartum }\end{array}$ & $\begin{array}{l}\text { Magnesium } \\
\text { for } 24 \text { hours } \\
\text { postpartum }\end{array}$ & $\begin{array}{l}\text { Eclampsia in } \\
\text { the first } 24 \\
\text { hours } \\
\text { postpartum }\end{array}$ \\
\hline Total: & $\begin{array}{l}2,183(1,088 \text { vs } \\
1,095)\end{array}$ & 12 countries & 8 non-blinded & $\begin{array}{l}1 \text { - loading } \\
\text { dose only a } 1- \\
\text { none } \\
\text { postpartum } 1 \\
\text { - until diuresis } \\
2-6 \text { hours } 3- \\
12 \text { hours }\end{array}$ & - & - \\
\hline
\end{tabular}

Data are presented as total number ( $n$ early magnesium discontinuation vs $n$ magnesium continued 24 hours) as number (percentage) or as mean \pm standard deviation.

Abbreviations: BP, blood pressure; g, gram; iv, intravenous; $\mathrm{mL}$, milliliter; NR, not reported; vs, versus ${ }^{\mathrm{a}}$ loading dose administered intrapartum and not continued intrapartum or postpartum

Table 2. Maternal delivery and postpartum characteristics (Magnesium early discontinuation versus standard 24-hour regimen)

\begin{tabular}{|c|c|c|c|}
\hline Study & Mean GA (wk) at delivery & Antihypertensive medication during labor & Placen \\
\hline Fontenot, 2005 & $33.4 \pm 3.7$ vs. $34.4 \pm 4.2$ & NR & NR \\
\hline Ehrenberg, 2006 & $38.7 \pm 1.7$ vs $38.7 \pm 1.7$ & NR & NR \\
\hline Darngawn, 2012 & $35.4 \pm 3.6$ vs $35.6 \pm 3.8$ & $11 / 75(14.7 \%)$ vs $14 / 75(18.7 \%)$ & NR \\
\hline Maia, 2014 & $36.8 \pm 3.0$ vs $37.2 \pm 4.9$ & $\mathrm{NR}$ & NR \\
\hline Kashanian, 2016 & $36.1 \pm 1.2$ vs $36.2 \pm 1.3$ & $13 / 79(16.4 \%)$ vs $17 / 91(16.5 \%)$ & NR \\
\hline Rimal, 2017 & $37.1 \pm 3.6$ vs $37.4 \pm 4.1$ & $\mathrm{NR}$ & $1 / 30(8$ \\
\hline Vigil-De Gracia, 2017 & $36.1 \pm 3.1$ vs $36.2 \pm 2.8$ & NR & NR \\
\hline Vigil-De Gracia, 2018 & $36.3 \pm 4.9$ vs $36.3 \pm 3.6$ & NR & $14 / 558$ \\
\hline Total or Standard Mean: & 36.3 vs 36.5 & $24 / 154(15.6 \%)$ vs $31 / 166(18.7 \%)$ & $15 / 588$ \\
\hline
\end{tabular}


Data are presented as total number ( $n$ intervention / control) as number (percentage) or as mean \pm standard deviation,

Abbreviations: GA, gestational age; NR, not reported; vs; versus

Table 3. Primary and secondary postpartum outcomes (Magnesium early discontinuation versus standard 24-hour regimen)

\begin{tabular}{lll}
\hline Study & Postpartum eclampsia & Magnesium extended past p \\
\hline Fontenot, 2005 & $0 / 48(0 \%)$ vs $0 / 50(0 \%)$ & NR \\
Ehrenberg, 2006 & $0 / 101(0 \%)$ vs $0 / 95(0 \%)$ & $7 / 101(6.9 \%)$ vs $1 / 95(1.1 \%)$ \\
Darngawn, 2012 & $0 / 75(0 \%)$ vs $0 / 75(0 \%)$ & $1 / 75(1.3 \%)$ vs $0 / 75(0 \%)$ \\
Maia, 2014 & $0 / 56(0 \%)$ vs $0 / 56(0 \%)$ & $3 / 56(5.4 \%)$ vs $0 / 56(0 \%)$ \\
Kashanian, 2016 & $1 / 79(1.2 \%)$ vs $0 / 91(0 \%)$ & $1 / 79(1.2 \%)$ vs NR \\
Rimal, 2017 & $2 / 30(16.6 \%)$ vs $1 / 30(8.3 \%)$ & $2 / 30(16.6 \%)$ vs $1 / 30(8.3 \%)$ \\
Vigil-De Gracia, 2017 & $0 / 141(0 \%)$ vs $0 / 143(0 \%)$ & $0 / 141(0 \%)$ vs $0 / 143(0 \%)$ \\
Vigil-De Gracia, 2018 & $2 / 558(0.35 \%)$ vs $1 / 555(0.2 \%)$ & $2 / 558(0.35 \%)$ vs $1 / 555(0.2 \%)$ \\
Studies total (intervention vs control) & 8 studies, $5 / 1088(0.5 \%)$ vs $2 / 1095(0.2 \%)$ & 6 studies, $15 / 961(1.6 \%)$ vs $3 / 95$ \\
$\mathbf{I}^{\mathbf{2}}$ & $0 \%$ & $0 \%$ \\
RR (95\% Confidence interval) & $2.25(0.5-9.9)$ & $\mathbf{3 . 7}(\mathbf{1 . 2 - 1 1 . 5 )}$ \\
\hline
\end{tabular}

Data are presented as total number ( $n$ early magnesium discontinuation vs $n$ magnesium continued 24 hours as number (percentage) or as mean \pm standard deviation. Bold values indicate statistical significance.

Abbreviations: BP, blood pressure; g, gram; iv, intravenous; hr, hour; NR, not reported; vs, versus ${ }^{\mathrm{a}}$ pain was reported as less in the intervention group ${ }^{\mathrm{b}} 17$ women demonstrated evidence of magnesium toxicity, their symptoms were not specified by the published studies.

Table 4. Characteristics of women with eclampsia

\begin{tabular}{|c|c|c|c|c|c|c|c|}
\hline $\begin{array}{l}\text { Patient } \\
\text { number }\end{array}$ & Study & $\begin{array}{l}\text { Randomized } \\
\text { to no } \\
\text { postpar- } \\
\text { tum } \\
\text { magne- } \\
\text { sium or } \\
\text { early } \\
\text { discon- } \\
\text { tinuation } \\
\text { vs } \\
24 \text {-hour } \\
\text { regimen }\end{array}$ & $\begin{array}{l}\text { Intervention } \\
\text { regimen }\end{array}$ & $\begin{array}{l}\text { Receiving } \\
\text { magne- } \\
\text { sium at } \\
\text { the time } \\
\text { of } \\
\text { seizure? }\end{array}$ & $\begin{array}{l}\text { Amount } \\
\text { of mag- } \\
\text { nesium } \\
\text { received } \\
\text { prior to } \\
\text { eclamp- } \\
\text { sia }\end{array}$ & $\begin{array}{l}\text { Timing } \\
\text { of post- } \\
\text { partum } \\
\text { eclamp- } \\
\text { sia }\end{array}$ & $\begin{array}{l}\text { Management } \\
\text { of } \\
\text { eclamp- } \\
\text { sia }\end{array}$ \\
\hline 1 & $\begin{array}{l}\text { Kashanian, } \\
2016\end{array}$ & $\begin{array}{l}\text { Early } \\
\text { discontinuation }\end{array}$ & 12 hours & No & NR & $\begin{array}{l}\text { At } 16 \\
\text { hours }\end{array}$ & $\begin{array}{l}\text { Magnesium } \\
\text { was } \\
\text { continued } \\
\text { for } 24 \\
\text { hours }\end{array}$ \\
\hline
\end{tabular}




\begin{tabular}{|c|c|c|c|c|c|c|c|}
\hline $\begin{array}{l}\text { Patient } \\
\text { number }\end{array}$ & Study & $\begin{array}{l}\text { Randomized } \\
\text { to no } \\
\text { postpar- } \\
\text { tum } \\
\text { magne- } \\
\text { sium or } \\
\text { early } \\
\text { discon- } \\
\text { tinuation } \\
\text { vs } \\
\text { 24-hour } \\
\text { regimen }\end{array}$ & $\begin{array}{l}\text { Intervention } \\
\text { regimen }\end{array}$ & $\begin{array}{l}\text { Receiving } \\
\text { magne- } \\
\text { sium at } \\
\text { the time } \\
\text { of } \\
\text { seizure? }\end{array}$ & $\begin{array}{l}\text { Amount } \\
\text { of mag- } \\
\text { nesium } \\
\text { received } \\
\text { prior to } \\
\text { eclamp- } \\
\text { sia }\end{array}$ & $\begin{array}{l}\text { Timing } \\
\text { of post- } \\
\text { partum } \\
\text { eclamp- } \\
\text { sia }\end{array}$ & $\begin{array}{l}\text { Managemen } \\
\text { of } \\
\text { eclamp- } \\
\text { sia }\end{array}$ \\
\hline 2 & $\begin{array}{l}\text { Rimal, } \\
2017\end{array}$ & $\begin{array}{l}\text { No post- } \\
\text { partum } \\
\text { magnesium }\end{array}$ & $\begin{array}{l}\text { Loading } \\
\text { dose only }\end{array}$ & NR & NR & NR & $\begin{array}{l}\text { Magnesium } \\
\text { 2g IV per } \\
\text { hour until } \\
24 \text { hours } \\
\text { after } \\
\text { seizure }\end{array}$ \\
\hline 3 & $\begin{array}{l}\text { Rimal, } \\
2017\end{array}$ & $\begin{array}{l}\text { No post- } \\
\text { partum } \\
\text { magnesium }\end{array}$ & $\begin{array}{l}\text { Loading } \\
\text { dose only }\end{array}$ & NR & NR & NR & $\begin{array}{l}\text { Magnesium } \\
2 \mathrm{~g} \text { IV per } \\
\text { hour until } \\
24 \text { hours } \\
\text { after } \\
\text { seizure }\end{array}$ \\
\hline 4 & $\begin{array}{l}\text { Rimal, } \\
2017\end{array}$ & 24-hour & & NR & NR & NR & $\begin{array}{l}\text { Magnesium } \\
2 \mathrm{~g} \text { IV per } \\
\text { hour until } \\
24 \text { hours } \\
\text { after seizure }\end{array}$ \\
\hline 5 & $\begin{array}{l}\text { Vigil-De } \\
\text { Gracia, } \\
2018\end{array}$ & $\begin{array}{l}\text { No post- } \\
\text { partum } \\
\text { magnesium }\end{array}$ & $\begin{array}{l}\text { No post- } \\
\text { partum } \\
\text { magnesium }\end{array}$ & No & NR & $\begin{array}{l}\text { Within } 6 \\
\text { hours } \\
\text { postpartum }\end{array}$ & $\begin{array}{l}\text { Received a } \\
\text { loading } \\
\text { dose of } \\
\text { magne- } \\
\text { sium } 4 \mathrm{~g} \\
\text { followed } \\
\text { by mainte- } \\
\text { nance dose } \\
\text { of } 1 \mathrm{~g} \text { per } \\
\text { hour for } \\
\text { additional } \\
24 \text { hours }\end{array}$ \\
\hline
\end{tabular}




\begin{tabular}{|c|c|c|c|c|c|c|c|}
\hline $\begin{array}{l}\text { Patient } \\
\text { number }\end{array}$ & Study & $\begin{array}{l}\text { Randomized } \\
\text { to no } \\
\text { postpar- } \\
\text { tum } \\
\text { magne- } \\
\text { sium or } \\
\text { early } \\
\text { discon- } \\
\text { tinuation } \\
\text { vs } \\
24 \text {-hour } \\
\text { regimen }\end{array}$ & $\begin{array}{l}\text { Intervention } \\
\text { regimen }\end{array}$ & $\begin{array}{l}\text { Receiving } \\
\text { magne- } \\
\text { sium at } \\
\text { the time } \\
\text { of } \\
\text { seizure? }\end{array}$ & $\begin{array}{l}\text { Amount } \\
\text { of mag- } \\
\text { nesium } \\
\text { received } \\
\text { prior to } \\
\text { eclamp- } \\
\text { sia }\end{array}$ & $\begin{array}{l}\text { Timing } \\
\text { of post- } \\
\text { partum } \\
\text { eclamp- } \\
\text { sia }\end{array}$ & $\begin{array}{l}\text { Managemen } \\
\text { of } \\
\text { eclamp- } \\
\text { sia }\end{array}$ \\
\hline 6 & $\begin{array}{l}\text { Vigil-De } \\
\text { Gracia, } \\
2018\end{array}$ & $\begin{array}{l}\text { No post- } \\
\text { partum } \\
\text { magnesium }\end{array}$ & $\begin{array}{l}\text { No post- } \\
\text { partum } \\
\text { magnesium }\end{array}$ & No & NR & $\begin{array}{l}\text { Within } 6 \\
\text { hours } \\
\text { postpartum }\end{array}$ & $\begin{array}{l}\text { Received a } \\
\text { loading } \\
\text { dose of } \\
\text { magne- } \\
\text { sium } 4 \mathrm{~g} \\
\text { followed } \\
\text { by mainte- } \\
\text { nance dose } \\
\text { of } 1 \text { g per } \\
\text { hour for } \\
\text { additional } \\
24 \text { hours }\end{array}$ \\
\hline 7 & $\begin{array}{l}\text { Vigil-De } \\
\text { Gracia, } \\
2018\end{array}$ & 24-hour & & Yes & NR & $\begin{array}{l}\text { Within } 6 \\
\text { hours } \\
\text { postpartum }\end{array}$ & $\begin{array}{l}\text { Received a } \\
\text { maintenance } \\
\text { dose of } 1 \mathrm{~g} \\
\text { per hour for } \\
\text { additional } \\
24 \text { hours }\end{array}$ \\
\hline
\end{tabular}

Abbreviations: g, gram; iv, intravenous; mins, minutes; vs, versus

Table 5. Secondary postpartum outcomes (Magnesium early discontinuation versus standard 24-hour regimen)

\begin{tabular}{|c|c|c|c|c|}
\hline Study & $\begin{array}{l}\text { Time to } \\
\text { ambulation (hr) }\end{array}$ & $\begin{array}{l}\text { Time to } \\
\text { initiation of } \\
\text { breastfeeding } \\
\text { (hr) }\end{array}$ & $\begin{array}{l}\text { Duration of } \\
\text { urinary } \\
\text { catheter (hr) }\end{array}$ & $\begin{array}{l}\text { Total } \\
\text { postpartum } \\
\text { hospital stay } \\
\text { (days) a }^{\text {days }}\end{array}$ \\
\hline Fontenot, 2005 & $\mathrm{NR}$ & $\mathrm{NR}$ & $\mathrm{NR}$ & $\begin{array}{l}3.5 \pm 1.1 \text { vs } \\
3.1 \pm 1.1\end{array}$ \\
\hline $\begin{array}{l}\text { Ehrenberg, } \\
2006\end{array}$ & NR & NR & NR & $\begin{array}{l}1.9 \pm 0.9 \mathrm{vs} \\
2.1 \pm 1.0\end{array}$ \\
\hline $\begin{array}{l}\text { Darngawn, } \\
2012\end{array}$ & $\mathrm{NR}$ & NR & NR & $\mathrm{NR}$ \\
\hline Maia, 2014 & $\begin{array}{l}18.8 \pm 4.9 \text { vs } 25.8 \\
\pm 6.9\end{array}$ & NR & $\begin{array}{l}14.3 \pm 3.7 \text { vs } 25.3 \\
\pm 3.5\end{array}$ & NR \\
\hline $\begin{array}{l}\text { Kashanian, } \\
2016\end{array}$ & $\mathrm{NR}$ & $\mathrm{NR}$ & $\mathrm{NR}$ & $\mathrm{NR}$ \\
\hline
\end{tabular}




\begin{tabular}{|c|c|c|c|c|}
\hline Study & $\begin{array}{l}\text { Time to } \\
\text { ambulation (hr) }\end{array}$ & $\begin{array}{l}\text { Time to } \\
\text { initiation of } \\
\text { breastfeeding } \\
\text { (hr) }\end{array}$ & $\begin{array}{l}\text { Duration of } \\
\text { urinary } \\
\text { catheter }(\mathrm{hr})\end{array}$ & $\begin{array}{l}\text { Total } \\
\text { postpartum } \\
\text { hospital stay } \\
\text { (days) }^{\text {a }}\end{array}$ \\
\hline Rimal, 2017 & NR & NR & NR & $\begin{array}{l}4.2 \pm 1.2 \text { vs } \\
4.7 \pm 1.5\end{array}$ \\
\hline Vigil-De & $10.9 \pm 5.3$ vs & $\begin{array}{l}25.7 \pm 19.8 \text { vs } \\
36.5+168\end{array}$ & NR & NR \\
\hline Vigil-De & $11.8 \pm 10.8 \mathrm{vs}$ & $17.1 \pm 16.8 \mathrm{vs}$ & NR & NR \\
\hline Gracia, 2018 & $18.1 \pm 10.6$ & $24.1 \pm 17.1$ & & \\
\hline $\begin{array}{l}\text { Total or } \\
\text { standard mean }\end{array}$ & 13.8 vs 22.9 & 21.4 vs 30.3 & 14.3 vs 25.3 & 3.2 vs 3.3 \\
\hline $\begin{array}{l}\text { Studies total } \\
\text { (intervention vs } \\
\text { control) }\end{array}$ & $\begin{array}{l}3 \text { studies (755 vs } \\
754 \text { ) }\end{array}$ & $\begin{array}{l}2 \text { studies (699 vs } \\
698 \text { ) }\end{array}$ & 1 study (180 vs 142 ) & $\begin{array}{l}3 \text { studies (179 vs } \\
175)\end{array}$ \\
\hline $\mathbf{I}^{2}$ & $98 \%$ & $60 \%$ & - & $78 \%$ \\
\hline $\begin{array}{l}\text { MD }(95 \% \\
\text { Confidence } \\
\text { interval) }\end{array}$ & $\begin{array}{l}-9.1(-14.7 \\
-3.6)\end{array}$ & $\begin{array}{l}-8.4(-12.0 \\
-4.8)\end{array}$ & - & $-0.04(-0.6,0.5)$ \\
\hline
\end{tabular}

Data are presented as total number ( $n$ early magnesium discontinuation vs $n$ magnesium continued 24 hours as number (percentage) or as mean \pm standard deviation. Bold values indicate statistical significance

Abbreviations: BP, blood pressure; g, gram; iv, intravenous; hr, hour; MD, mean difference; NR, not reported; vs, versus

a Data separated by mode of delivery not reported or available

Table 6: Reasons to consider early discontinuation of magnesium versus continuation of magnesium for 24-hours

\begin{tabular}{ll}
\hline Consider no magnesium or early & $\begin{array}{l}\text { Consider continuation of magnesium for } \\
\text { discontinuation in postpartum period }\end{array}$ \\
\hline
\end{tabular}

If the woman received $>8 \mathrm{gm}$ of magnesium prior $\quad$ Neurologic symptoms ${ }^{\mathrm{c}}$ Eclampsia intrapartum ${ }^{\mathrm{d}}$ to delivery ${ }^{a}$ Diuresis $>100 \mathrm{~mL} /$ hour $^{\mathrm{b}} \quad$ HELLP syndrome $^{\mathrm{d}}$

${ }^{a}$ based off of the inclusion criteria for study by Vigil-De Garcia ${ }^{16}$

${ }^{\mathrm{b}}$ based off of the inclusion criteria for study by Fontenot ${ }^{11}$

${ }^{c}$ based off of relatively low numbers needed to treat of $1 / 36$ of patients to avoid one episode of eclampsia ${ }^{19}$

${ }^{\mathrm{d}}$ based off of the exclusion criteria for studies include in this meta-analysis 


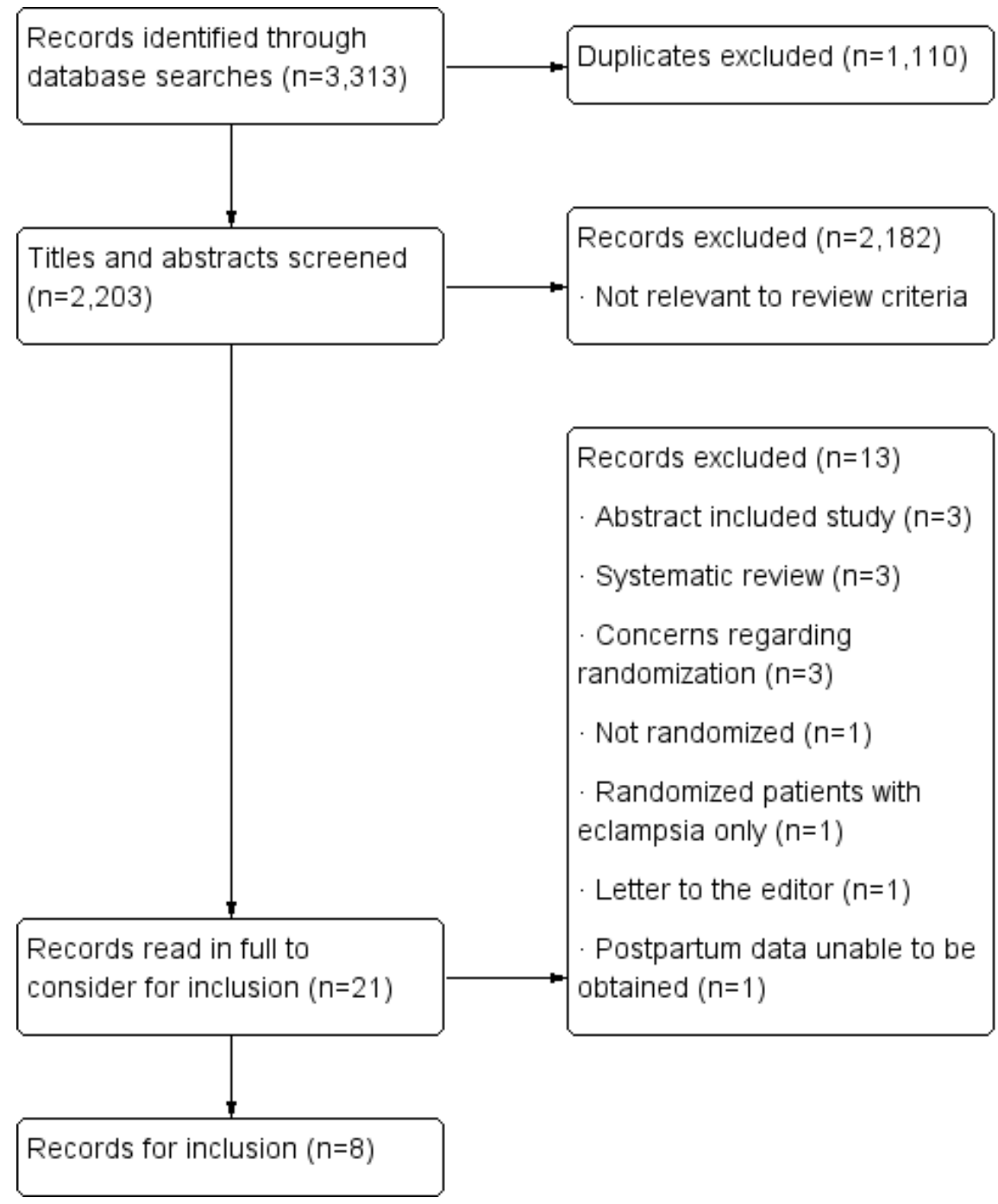

\section{Hosted file}

Risk of bias summary.Figure2A.png available at https://authorea.com/users/303203/articles/ 433302-early-magnesium-discontinuation-postpartum-and-eclampsia-risk-a-systematicreview-and-meta-analysis

\section{Hosted file}

Risk of bias graph.Figure2B.png available at https://authorea.com/users/303203/articles/ 433302-early-magnesium-discontinuation-postpartum-and-eclampsia-risk-a-systematicreview-and-meta-analysis 


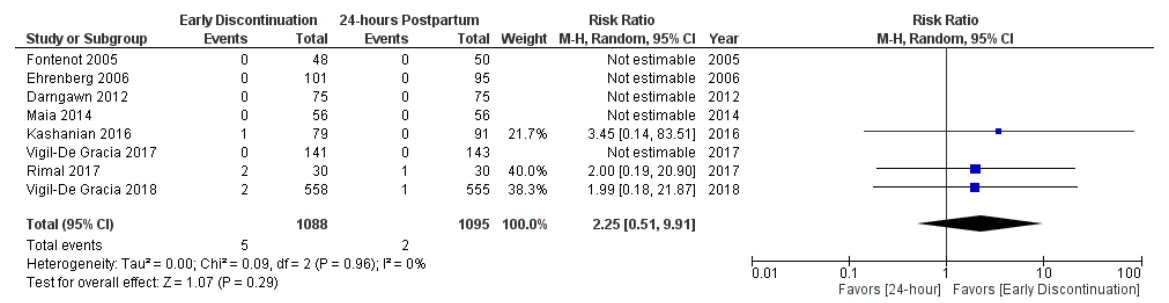

